\title{
PENGARUH LAYANAN BIMBINGAN KELOMPOK TERHADAP ETIKA PERGAULAN SISWA
}

Oleh:

\author{
Sunarti $^{1)}$, Nani Restati Siregar ${ }^{2)}$ \\ 1) 2) Jurusan Bimbingan dan Konseling
}

Fakultas Keguruan dan Ilmu Pendidikan, Universitas Halu Oleo

Email: ${ }^{1)}$ sunartikonseling@gmail.com ${ }^{2)}$ naniresilham@yahoo.com

\begin{abstract}
ABSTRAK
Penelitian ini bertujuan untuk meningkatkan etika pergaulan siswa kelas VIII SMP Negeri 07 Kendari melalui bimbingan kelompok. Subjek dalam penelitian ini berjumlah 10 siswa. Jenis penelitian ini adalah penelitian pre eksperimen dengan desain one-grup pre test dan post test.. Data Yang dikumpulkan dengan menggunakan angket etika pergaulan. Hasil uji hipotesis dengan menggunakan wilcoxon signed rank dengan taraf signifikan $\alpha=0,05$ diperoleh $\mathrm{P}_{\text {value }}=0,005$. $\mathrm{P}_{\text {value }}<\alpha(0,005<0,05)$ dengan demikian $\mathrm{H}_{0}$ ditolak. Maka dapat disimpulkan bahwa layanan bimbingan kelompok dapat berpengaruh terhadap etika pergaulan siswa di SMP Negeri 07 Kendari.
\end{abstract}

Kata Kunci: Etika Pergaulan, Bimbingan Kelompok

THE EFFECT OF GROUP GUIDANCE SERVICES ON STUDENTS 'ETHICS

\begin{abstract}
The purpose of the research was to improve the students' ethics of relation eight graders of public junior high school 7 Kendari. the subjects of the research were 10 students. This was pre-experimental research with onegroup pre test and post test design. Data were collected through the ethic of relation questionnaires. Based on hypothesis test using Wilcoxon signed rank test, it was found that it's significant was $a=0,05$ with its Pvalue $=0.005$. Pvalue $<a=0.05$. The test result indicates that $H o$ is rejected. It can therefore be concluded that group guidance service has an effect on the students' relation ethics of the eight graders public junior high school 7 Kendari.
\end{abstract}

Keywords: The ethics of Relation, Group Guidance 


\section{Pendahuluan}

Pergaulan merupakan hubungan yang dijalani oleh manusia yang meliputi perasaan, tingkah laku, dan jati diri yang ada di dalam diri manusia. Dalam pergaulan antara siswa, baik di rumah, sekolah maupun masyarakat selalu diperlukan etika pergaulan. Hal ini merupakan pembawaan siswa bahwa siswa memiliki rasa ingin dihargai oleh siswa lain dan sekaligus ingin menghargai siswa lain. Rifai dkk ( 2012: 279) mengemukakan etika pergaulan dapat diartikan sebagai adat kebiasaan tentang perilaku yang disepakati bersama sebagai sesuatu yang baik dalam pertemanan. Maksudnya tidak lain adalah kebiasaan yang baik dalam menjalin hubungan sebagai teman. Etika pergaulan sebagai suatu kebiasaan memiliki sifat khusus, baik dalam bentuk maupun keluasannya. Etika pergaulan sangat berhubungan dengan perilaku individu dalam menjalin hubungan dengan individu lain di masyarakat dan perilaku tesebut tidaklah bersifat universal, karena memiliki kekhususan yang menjadi ciri masyarakat yang bersangkutan.

Masalah etika pergaulan adalah masalah siswa pada umumnya, di mana pun siswa berada pasti etika ikut berperan sebagai pedoman tingkah laku baik-buruk dalam pergaulan. Siswa dalam pergaulannya memerlukan pedoman tingkah laku agar pergaulan sesama teman sebaya dapat berjalan dengan baik sesuai dengan norma masyarakat atau sesuai dengan norma agama yang dianutnya, sehingga mereka terhindar dari pergaulan yang menyimpang, terhindar dari berbagai masalah dan terhindar dari konflik.

Siswa sebagai makhluk sosial yang saling membutuhkan satu sama lain, memiliki kekurangan dan kelebihan serta membutuhkan bantuan siswa lain, siswa bisa hidup karena saling tolong menolong. Dalam kehidupan sehari-hari terjadi pergaulan antara siswa di kalangan masyarakat banyak hal-hal yang perlu diketahui karena siswa yang jumlahnya lebih dari satu harus memiliki aturan-aturan yang dapat memisahkan antara hak dan kewajiban masing-masing siswa. Demikian juga di lingkungan sekolah, siswa harus berinteraksi dengan siswa lain, baik dengan guru, teman maupun semua orang yang ada di lingkungan sekolah. Abdullah (2006: 646) mengemukakan seseorang harus menciptakan pergaulan yang sopan dan santun, menghargai hak-hak sesema manusia. Seorang tidak boleh merasa lebih baik dari yang lain dan harus rendah hati di hadapan sesama.

Etika pergaulan merupakan suatu hal yang mencerminkan moral, setiap siswa yang harus diketahui dan dipahami oleh semua siswa yang berada dalam lingkungan sekolah dan lingkungan masyarakat. Karena di manapun dan kapanpun siswa selalu diperhadapkan dengan siswa-siswa lain yang ada di sekitarnya. Apabila tidak menyadari dan memahami situasi yang ada di sekitarnya maka bisa saja melakukan suatu hal yang melanggar peraturan yang ada di lingkungan sekolah. Oleh karena itu, sangat penting untuk menanamkan pemahaman kepada siswa mengenai etika pergaulan agar mereka mampu mengaplikasikan di dalam kehidupanya.

Siswa harus mulai dapat bertanggung jawab mengendalikan perilakunya sendiri yang sebelumnya menjadi tanggung jawab orang tua pada saat masa kanak-kanak, sehingga perilakunya tidak melanggar peraturan yang berlaku dalam lingkungan sekolah maupun masyarakat. Situasi pergaulan sangat menentukan perkembangan moral siswa, dilihat dari siapa dan dengan siapa siswa bergaul, lingkungan seperti apa dan apa yang terjadi dalam pergaulan itu. Siswa tidak harus dibatasi dalam bergaul agar mengenal lingkungan secara lebih luas, karena pada masa ini siswa memiliki tugas perkembangan yang harus mereka selesaikan sehingga siswa merasa bahagia dengan apa yang mereka capai selama masa tersebut. Dengan begitu siswa dapat membedakan mana hal yang baik dan mana hal yang buruk.

Siswa seharusnya mengembangkan etika pergaulan yang baik yang merupakan cara siswa bertingkah laku terhadap siswa lain yang di tunjukkan dengan cara menghormati siswa lain, bersikap ramah dan sopan terhadap siswa lain dalam hal ini siswa harus mampu berkomunikasi dengan baik dengan siswa lain tidak memanggil siswa lain dengan panggilan yang kasar dan mampu mengendalikan emosi sehingga tidak terjadi pertengkaran antar sesama siswa. Strike dan Soltis (dalam Kartilah, 2016 : 69) mengemukakan etika pergaulan bertujuan untuk mengatasi suatu pergaulan yang baik dan yang buruk agar dalam berkomunikasi dan hubungan dengan orang atau individu lain dapat menajalin hubungan dengan baik. Namun, hal tersebut berbeda dengan yang terjadi di SMP Negeri 7 Kendari.

Berdasarkan hasil wawancara dengan Wakil Kepala Sekolah bagian kesiswaan, diketahui bahwa siswa di sana memiliki etika pergaulan yang kurang baik seperti, siswa di sekolah tersebut selalu menunjukkan sikap yang tidak sopan terhadap teman atau bahkan orang tua dan guru, siswa selalu menunjukkan perilaku yang tidak sopan seperti 
siswa memaksakan kehendaknya sendiri, siswa memanggil temannya dengan panggilan yang kasar, sering bertengkar dengan teman, sering menghina dan mengejek teman. Hasil wawancara tersebut diperkuat oleh hasil pengamatan (observasi) yang dilakukan oleh penulis yang menemukan beberapa siswa memiliki etika pergaulan yang rendah, seperti siswa selalu berkata kasar kepada temannya, siswa menunjukkan sikap yang kurang sopan kepada guru, siswa mengejek temannya, siswa memanggil temannya dengan menggunakan nama orang tua temannya, siswa kurang mampu mengontrol emosinya sehingga mengakibatkan pertengkarang antara sesama siswa.

Dari berbagai fenomena tersebut, siswa banyak mendapatkan masalah akibat dari perbuatannya tersebut, contohnya siswa selalu bertengkar dengan temannya, siswa tidak menghargai pendapat siswa lain, siswa tidak sopan dalam berbicara dengan siswa lain bahkan terhadap gurunya, oleh karena itu siswa tersebut selalu diberikan hukum oleh guru-guru yang ada di sekolah tersebut bahkan selalu dipanggil di ruang guru untuk mendapatkan hukuman dan mendapatkan surat panggilan untuk orang tuannya.

Dari berbagai masalah tersebut ada banyak cara yang dapat digunakan oleh guru bimbingan dan konseling (BK) untuk meminimalisir etika pergaulan siswa, salah satunya adalah layanan bimbingan kelompok. Layanan bimbingan kelompok membawa siswa ke dalam dinamika kelompok atau kehidupan kelompok. Melalui dinamika kelompok aggota kelompok dapat membahas topik secara mendalam mengenai etika pergaulan sehingga dapat mendorong keaktifan dan sikap saling menghormati. Folastri dan Itsar (2016: 20) mengemukakan bahwa layanan bimbingan kelompok merupakan suatu kegiatan yang diselenggarakan oleh tenaga profesional bimbingan dan konseling terhadap suatu kelompok tertentu unuk mengembangkan kemampuan anggota kelompok ke arah kemandirian dengan memanfaatkan dinamika kelompok.

Bimbingan kelompok ini membahas topik yang dialami oleh masing-masing siswa ketika mengikuti bimbingan kelompok di dalamnya juga diberi kesempatan untuk saling mengemukakan pendapat, memberikan saran maupun ide-ide dalam permainan, menanggapi, saling menghargai pendapat anggota lain, saling berkomunikasi dengan baik dan tidak menyinggung perasaan siswa lain untuk menciptakan dinamika kelompok. Selain itu hal yang paling utama dari bimbingan kelompok ini adalah semua anggota kelompok dalam hal ini siswa yang mengikuti kegiatan bimbingan kelompok bisa belajar tentang etika pergaulan, seperti menghargai pendapat orang lain, tidak menyinggung perasaan orang lain, belajar saling menghormati, berempati dengan anggota lain, memberikan kesempatan dan meningkatkan etika pergaulannya siswa dengan baik. Layanan bimbingan kelompok mampu memahami nilai-nilai yang berlaku dan hidup dengan tuntutan nilai-nilai tersebut dan memiliki kesensitifan yang tinggi terhadap kebutuhan dan perasaan orang lain.

Berdasarkan penjelasan tersebut peneliti memiliki inisiatif untuk melakukan penelitian dengan judul Pengaruh Layanan Bimbingan Kelompok Terhadap Etika Pergaulan Siswa. Tujuan dari penelitian ini adalah untuk mengetahui pengaruh layanan bimbingan kelompok terhadap Etika Pergaulan Siswa.

Etika sering disebut disebut filsafat moral. Etika merupakan cabang filsafat yang berbicara mengenai tindakan manusia dalam kaitanya dengan tujuan hidupnya. Etika membahas baik-buruk atau benar tidaknya tingkah laku dan tindakan manusia serta sekaligus menyoroti kewajiban-kewajiban manusia. Etika mempersoalkan bagaimana manusia seharusnya berbuat atau bertindak. Etika berarti ilmu tentang apa yang biasa dilakukan atau ilmu tentang adat kebiasaan dengan memakai istilah modern, dapat dikatakan juga bahwa etika membahas "konvensi-konvensi sosial" yang ditemukan dalam masyarakat (Bertens, 2013: 4).

Rifai dkk (2012: 279) mengemukakan etika pergaulan dapat diartikan sebagai adat kebiasaan tentang perilaku yang disepakati bersama sebagai sesuatu yang baik dalam pertemanan. Maksudnya tidak lain adalah kebiasaan yang baik dalam menjalin hubungan sebagai teman. Etika pergaulan sebagai suatu kebiasaan memiliki sifat khusus, baik dalam bentuk maupun keluasannya. Etika pergaulan sangat berhubungan dengan perilaku individu dalam menjalin hubungan dengan individu lain di masyarakat dan perilaku tesebut tidaklah bersifat universal, karena memiliki kekhususan yang menjadi ciri masyarakat yang bersangkutan. Meskipun demikian tidaklah semua perilaku bersifat kedaerahan, tetapi ada pula perilaku yang yang bersifat universal seperti ciri manusia yang bermartabat, seperti perilaku menghargai hak asasi manusia dengan tidak berbuat kekerasan kepada sesama manusia.

Strike dan Soltis (dalam Aggriani dkk, 2016: 69) mengemukakan etika pergaulan adalah 
suatu hubungan tingkah laku individu yang di dalamnya terdapat suatu norma dan nilai-nilai yang digunakan dalam kehidupan sehari-hari, serta merupakan tolak ukur tingkah laku individu yang digunakan masyarakat untuk menentukan baik buruknya suatu tindakan manusia dalam kehidupan sehari-hari.

Keraf (dalam Ruslan, 2007: 39-40) mengemukakan bahwa dalam membahas etika sebagai ilmu yang menyelidiki tentang tanggapan kesusilaan atau etis sama halnya dengan berbicara moral (mores). Manusia yang disebut etis ialah manusia yang secara utuh dan menyeluruh mampu memenuhi hajat hidupnya dalam rangka asas keseimbangan antara kepentingan pribadi dengan pihak yang lainya, antara rohani dengan jasmaninya dan antara manusia sebagai makhluk berdiri sendiri dengan penciptanya, termasuk di dalamnya membahas nilai-nilai atau norma-norma yang dikaitkan dengan etika. Terdapat dua macam etika, sebagai berikut:

1. Etika deskriptif, adalah etika yang menelaah secara kritis dan rasional tentang sikap dan perilaku manusia, serta apa yang dikejar oleh setiap orang dalam hidupnya sebagai sesuatu yang bernilai. Artinya, etika deskriptif tersebut berbicara mengenai fakta apa adanya, yakni mengenai nilai dan perilaku manusia sebagai suatu fakta yang terkait dengan situasi dan realitas yang membudaya. Dapat disimpulkan kenyataan dalam penghayatan nilai atau tanpa nilai dalam suatu masyarakat yang dikaitkan dengan kondisi tertentu memungkinkan manusia dapat bertindak secara etis.

2. Etika normatif, adalah etika yang menetapkan berbagai sikap dan perilaku yang ideal dan seharusnya dimliki oleh manusia atau apa yang seharusnya dijalankan oleh manusia dan tindakan apa yang bernilai dalam hidup ini. Jadi etika normatif merupakan norma-norma yang dapat menuntun manusia agar bertindak secara baik dan menghindarkan hal-hal yang buruk, sesuai dengan kaidah atau norma yang disepakati dan berlaku di masyarakat.

Kartilah (2017: 5) menyatakan masa remaja merupakan masa transisi (peralihan) dari masa kanak-kanak menuju dewasa, yaitu saat manusia tidak mau lagi diperlakukan oleh lingkungan keluarga masyarakat sebagai anak-anak, tetapi dilihat dari pertumbuhan fisik, perkembangan psikis dan mentalnya belum bisa menujukkan tanda-tanda dewasa. Pergaulan remaja yang sehat adalah pergaulan yang sesuai etika pergaulan. Cara-cara mengembangkan pergaulan sehat remaja di antaranya dapat dilakukan:

1. Adanya kesadaran beragama bagi remaja.

2. Memiliki rasa setia kawan

3. Pandai berterima kasih

4. Mengisi waktu dengan kegiatan yang positif

5. Laki-laki dan perempuan memiliki batasanbatasan tetentu.

6. Menstabilkan emosi/ menghargai perasaan orang lain.

7. Memiliki etika dalam pergaulan dan keterampilan berkomunikasi

Prayitno \& Amti (2013: 309), menyatakan bahwa bimbingan kelompok yaitu layanan bimbingan dan konseling yang memungkinkan sejumlah individu secara bersama-sama melalui dinamika kelompok memperoleh berbagai pengetahuan dari narasumber. Bimbingan kelompok adalah proses pemberian bantuan yang diberikan pada individu (siswa) dalam situasi kelompok. Selanjutnya, Abidin dan Budiyono (2010: 62-63) mengemukakan layanan bimbingan kelompok adalah layanan yang memungkinkan seseorangan secara bersama-sama mendapatkan berbagai pengetatahuan dari narasumber terutama dari konselor, konselor hal ini berguna untuk menunjang kehidupannya sehari-hari sebagai individu itu sendiri, pelajar, anggota keluarga dan anggota masyarakat serta untuk dasar pertimbangan dalam pengembalian keputusan.

Munro, Manthei \& Small (dalam Folastri dan Itsar, 2016: 30-31 ) mengemukakan dalam kegiatan layanan bimbingan kelompok memunyai asas-asas sebagai berikut:

1. Asas Kerahasiaan

Segala sesuatu yang dibahas dan muncul dalam kegiatan kelompok hendaknya menjadi "rahasia kelompok" yang hanya boleh diketahui oleh anggota kelompok dan tidak disebarluaskan ke luar kelompok. Seluruh anggota kelompok hendaknya menyadari benar hal ini dan berjanji dengan bersungguh-sungguh untuk melaksanakannya.

2. Asas Kesukarelaan

Kesukarelaan anggota kelompok dimulai sejak awal rencana pembentukan kelompok oleh pemimpin kelompok. Kesukarelaan terusmenerus dibina melalui upaya pemimpin kelompok dalam mengembangkan syarat-syarat kelompok yabg efektif dan penstrukturan tentang layanan bimbingan kelompok. 
3. Asas Kegiatan dan keterbukaan

Anggota kelompok secara aktif dan terbuka menampilkan diri tanpa rasa takut, malu ataupun ragu. Dinamika kelompok semakin tinggi, berisi dan bervariasi. Masukan dan sentuhan akan semakin kaya dan terasa. Para anggota dalam layanan bimbingan kelompok semakin dimungkinkan memperoleh hal-hal yang berharga dari layanan ini.

4. Asas Kekinian

Memberikan isi aktual dalam pembahasan yang dilakukan, aggota kelompok diminta untuk menyampaikan hal-hal yang terjadi dan berlaku sekarang ini. Hal-hal atau pengalaman yang telah lalu dianalisis dan disangkut-pautkan untuk kepentingan pembahasan hal-hal yang terjadi dan berlaku sekarang.

5. Asas Kenormatifan dan Keahlian

Dipraktikkan berkenaan dengan cara-cara berkomunikasi dan bertata-krama dalam kegiatan kelompok serta dalam mengemasi isi bahasa. Sedangkan asas keahlian ditunjukkan oleh pemimpin kelompok dalam mengelola kegiatan kelompok untuk mengembangankan proses dan isi pembahasan secara menyeluruh

Hartinah (2009: 114-115) mengatakan bahwa manfaat dan pentingnya bimbingan kelompok perlu mendapat penekanan yang sungguh-sungguh. Melalui bimbingan kelompok, para siswa:

1. Diberi kesempatan yang luas untuk berpendapat dan membicarakan berbagai hal yang terjadi di sekitarnya. Pendapat siswa tersebut dapat bermacam-macam, ada positif dan ada yang negatif. Semua pendapat tersebut, melalui dinamika kelompok dan berperannya pemimping kelompok diluruskan (bagi pendapat yang salah/ negatif), disinkronisasikan, dan dimantapkan sehingga para siswa tidak terjadi kesalah pahaman;

2. Memiliki pengetahuan yang objektif, tepat dan cukup luas tentang berbagai hal yang mereka bicarakan itu.

3. Pengetahuan yang objektif, tepat dan luas itu diharapkan menumbuhkan sikap yang positif terhadap keadaan siswa dan lingkungan yang bersangkut-paut dengan hal-hal yang mereka bicarakan di dalam kelompok. "sikap positif" di sini dimaksudkan: menolak hal-hal yang negatif dan menerima hal-hal yang positif.

4. Sikap positif ini lebih jauh diharapkan dapat menumbuhkan para siswa untuk menyusun program-program kegiatan untuk mewujudkan "penolakan terhadap yang negatif dan menerima terhadap hal-hal yang baik.

5. Lebih jauh lagi, program-program kegiatan itu diharapkan dapat mendorong siswa untuk melakukan kegiatan-kegiatan nyata dan langsung mendapatkan hasil sebagaimana yang telah diprogramkan sejak awal.

\section{Metode Penelitian}

Penelitian dilakukan di SMP Negeri 07 Kendari. Pemilihan tempat penelitian tersebut didasarkan dengan adanya masalah etika pergaulan yang burukdan kemudahan dalam operasional di lapangan, dan atas pertimbangan bahwa di tempat tersebut belum pernah dilakukan penelitian yang sejenis. Penelitian ini dilaksanakan selama 4 bulan dimulai dari bulan April 2018 sampai dengan Agustus 2018. Perlakuan dalam penelitian ini dilaksanakan selama 8 kali pertemuan dengan frekuensi pertemuan 3 kali dalam seminggu. Durasi waktu dalam pertemuan 2 x 45 menit.

Jenis dan desain penelitian ini yang digunakan adalah penelitian pra eksperimental design karena dalam penelitian ini yang diutamakan adalah perlakuan saja tanpa ada kelompok kontrol (Latipun, 2002: 68) serta dengan menggunakan teknik one group pre test-post test design karena variabel ini menawarkan hipotesis yang masuk akal (Julian dan Donald 1966: 17).

Subjek dalam penelitian berjumlah 10 orang siswa yang diambil dengan teknik purposive sampling, 7 orang siswa yang memiliki etika pergaulan yang rendah dan 3 orang siswa yang memilki etika pergaulan yang tinggi, dengan maksud menciptakan kondisi yang efektif dan adanya timbal balik serta saling berbagi informasi kepada siswa mengenai dampak yang diakibatkan dari rendanya etika pergaulan siswa tersebut.

Teknik pengumpulan data dalam penelitian ini angket etika pergaulan. Angket merupakan sebuah pernyataan-pernyataan yang digunakan untuk memperoleh informasi dari responden tentang diri pribadi atau hal-hal yang ia ketahui. Angket disusun berdasarkan etika pergaulan yang baik antara sesama manusia dari pedapat Abdullah (2006: 615), yaitu menghormati perasaan orang lain, memberi salam dan menjawab salam, pandai berterimah kasih, tidak boleh mengejek, jangan mencari kesalahan orang lain. Angket yang akan digunakan terlebih dahulu diuji coba, untuk memenuhi kriteria yang telah ditetapkan dalam penelitian ilmiah yaitu validitas dan realibilitas. Angket disajikan dengan menggunakan skala likert 
dengan kategori jawaban SS: Sangat Sesuai, S: Sesuai, TS: Tidak Sesuai, STS: Sangat Tidak Sesuai.

Teknik analisis data menggunakan analisis deskriptif persentase dan analisis statistik inferensial digunakan untuk menguji hipotesis penelitian. Pengujian hipotesis dilakukan dengan menggunakan statistika non parametik yaitu dengan uji wilcoxon signed rank untuk melihat ada tidaknya perbedaan gain score antara pre-test dan post-test pada kelompok eksperimen. Hal ini bertujuan untuk mengetahui perbedaan skor kontrol diri siswa pada saat sebelum diberikan treatment (pre-test), dan sesudah diberikan treatment (posttest).

\section{Hasil Penelitian dan Pembahasan Hasil Penelitian}

Analisis Deskriptif Skor Pre Test Etika Pergaulan Siswa

Gambaran etika pergaulan siswa kelas VIII di SMP Negeri 07 Kendari dapat diketahui berdasarkan hasil pengisian angket skala etika pergulan yang disebar pada 60 orang siswa. Dari data tersebut di ambil siswa 10 yang memiliki skor etika pergaulan yang tinggi, rendah, dan sangat rendah untuk untuk diberi perlakuan berupa layanan bimbingan kelompok. Untuk mengetahui gambaran etika pergaulan siswa sebelum diberikan perlakuan maka skor yang diperoleh subjek penelitian lebih dahulu dikonversikan ke dalam kategori penilaian dengan menggunakan analisis deskriptif sebagaimana yang disajikan dalam tabel berikut:

\section{Tabel 1}

Skor Pre Test Etika Pergaulan Siswa

\begin{tabular}{|c|c|c|c|c|}
\hline No. & Nama & Skor & $\%$ & Kriteria Pre test \\
\hline 1 & LD & 164 & $60,25 \%$ & Rendah \\
\hline 2 & $\overline{\mathrm{SA}}$ & 164 & $60,29 \%$ & Rendah \\
\hline 3 & $\mathrm{RS}$ & 114 & $41,91 \%$ & Sangat Rendah \\
\hline 4 & $\overline{\mathrm{DA}}$ & 162 & $59,55 \%$ & Rendah \\
\hline 5 & SA & 125 & $45,95 \%$ & Rendah \\
\hline 6 & HSI & 120 & $44,11 \%$ & Rendah \\
\hline 7 & $\overline{\mathrm{SL}}$ & 135 & $49,63 \%$ & Rendah \\
\hline 8 & $\mathrm{NM}$ & 198 & $72,79 \%$ & Tinggi \\
\hline 9 & $\overline{\mathrm{SM}}$ & 191 & $70,22 \%$ & Tinggi \\
\hline 10 & TA & 211 & $77,57 \%$ & Tinggi \\
\hline & Rata-rata & 159 & $58.23 \%$ & Rendah \\
\hline
\end{tabular}

Berdasarkan Tabel 1 di atas, etika pergaulan siswa kelas VIII di SMP Negeri 07 Kendari sebelum diberikan perlakuan (pre test) termasuk dalam kategori rendah. Hal ini dapat dilihat dari rata-rata persentase etika pergaulan siswa mencapai $58,23 \%$ dari 10 orang subjek penelitian.

Analisis Deskriptif Skor Post Test Etika Pergaulan Siswa

Gambaran etika pergaulan siswa kelas VIII di SMP Negeri 07 Kendari setelah diberikan perlakuan berupa layanan bimbingan kelompok dapat diketahui berdasarkan hasil analisis etika pergaulan siswa, sebagaimana yang tertera pada tabel berikut:

Tabel 2

Skor Post Test Etika Pergaulan Siswa

\begin{tabular}{|c|c|c|c|c|}
\hline No. & Nama & Skor & $\mathbf{\%}$ & Kriteria Post test \\
\hline 1 & LD & 207 & $76,10 \%$ & Tinggi \\
\hline 2 & SA & 217 & $79,77 \%$ & Tinggi \\
\hline 3 & RS & 218 & $80,14 \%$ & Tinggi \\
\hline 4 & DA & 222 & $81,61 \%$ & Tinggi \\
\hline 5 & SA & 210 & $77,20 \%$ & Tinggi \\
\hline 6 & HSI & 221 & $81,25 \%$ & Tinggi \\
\hline 7 & SL & 217 & $79,77 \%$ & Tinggi \\
\hline 8 & NM & 228 & $83,82 \%$ & Sangat Tinggi \\
\hline 9 & SM & 236 & $86,76 \%$ & Sangat Tinggi \\
\hline 10 & TA & 240 & $88,23 \%$ & Sangat Tinggi \\
\hline & Rata-rata & $\mathbf{2 2 1 , 6}$ & $81,47 \%$ & Tinggi \\
\hline
\end{tabular}

Berdasarkan tabel 2 di atas, etika pergaulan siswa setelah diberikan perlakuan (post test) mengalami perubahan dari kategori rendah menjadi kategori tinggi. Hal ini dapat dilihat dari rata-rata persentase yang diperoleh yakni sekitar 81,47\% dari 10 orang subjek penelitian.

Analisis Statistika Inferensial

Analisis data untuk mengetahui apakah layanan bimbingan kelompok dapat meningkatkan etika pergaulan siswa kelas VIII di SMP Negeri 07 Kendari secara signifikan, dilakukan dengan analisis statistik non parametric yaitu dengan uji wilcoxon signed rank untuk melihat ada tidaknya perbedaan gain score antara pre-test dan post-test pada kelompok eksperimen. Hal ini bertujuan untuk mengetahui signifikansi perbedaan skor etika pergaulan siswa pada saat sebelum diberikan treatment (pre-test) dan sesudah diberikan treatment (post-test). Berdasarkan analisis statistik inferensial dengan menggunakan uji wilcoxon pada taraf signifikansi $\alpha=0,05$ diperoleh $\mathrm{P}_{\text {value }}=0,005$. Kemudian dari hasil uji wilcoxon diperoleh $\mathrm{P}_{\text {value }}<$ $\alpha(0,005<0,05)$ dengan demikian $\mathrm{H}_{\mathrm{a}}$ diterima. Hal ini berarti layanan bimbingan kelompok dapat meningktakan etika pergaulan siswa. 


\section{Pembahasan}

Berdasarkan hasil analisis data dengan jumlah subjek penelitian sebanyak 10 siswa, dapat diketahui bahwa etika pergaulan siswa sebelum diberikan layanan bimbingan kelompok (pre test) termasuk dalam kategori rendah yaitu dalam persentase sebesar 58,23\%, sehingga etika pergaulan siswa perlu untuk ditingkatkan. Untuk meningkatkan etika pergaulan siswa, maka peneliti memberikan perlsakuan layanan bimbingan kelompok.

Prayitno \& Amti (2013: 309) menyatakan bahwa bimbingan kelompok yaitu layanan bimbingan dan konseling yang memungkinkan sejumlah peserta didik secara bersama-sama melalui dinamika kelompok memperoleh berbagai bahan dari narasumber. Bimbingan kelompok adalah proses pemberian bantuan yang diberikan pada individu dalam situasi kelompok. Bimbingan kelompok ditujukan untuk mencegah timbulnya masalah pada siswa dan mengembangkan potensi siswa. Pelaksanaan layanan bimbingan kelompok untuk meningkatkan etika pergaulan siswa dilakukan sebanyak delapan kali pertemuan dengan durasi selama 2 x 45 menit.

Setelah diberikan perlakuan (treatment) layanan bimbingan kelompok, siswa selanjutnya mengisi post test yang diberikan oleh peneliti. Tujuan dari pemberian post test adalah untuk mengetahui tingkat keberhasilan pelaksanaan perlakuan dan peningkatan etika pergaulan siswa. Berdasarkan hasil rata-rata etika pergaulan siswa setelah diberikan layanan bimbingan kelompok (post test) termasuk dalam kategori tinggi yaitu dengan persentase sebesar $81,47 \%$.

Berdasarkan hasil analisis data skor pre test dan skor post test tersebut maka dapat diketahui adanya peningkatan etika pegaulan siswa sebesar $23,013 \%$. Hal ini menunjukkan bahwa layanan bimbingan kelompok dapat meningkatkan etika pergaulan siswa di SMP Negeri 07 Kendari. Hal ini diperkuat dengan hasil analisis data statistik bahwa berdasarkan hasil perhitungan uji wilcoxon signed rank pada tabel test statistics diperoleh nilai Asymp. Sig. $(2$-tailed $)=0,005<0.05$, artinya $\mathrm{H}_{\mathrm{a}}$ diterima. Dengan kata lain etika pergaulan siswa dapat ditingkatkan melalui layanan bimbingan kelompok.

Hasil penelitian ini juga memperkuat hasil penelitian yang dilakukan oleh Muhayati (2013) dengan judul Meningkatkan Keterampilan Etika Pergaulan Melalui Layanan Bimbingan Kelompok Pada Siswa Kelas VIII F SMP Negeri 3 Demak Tahun Ajaran 2011/ 2012 yang menunjukkan adanya peningkatan keterampilan etika pergaulan setelah dilakukan layanan bimbingan kelompok, yang semula $46,29 \%$ menjadi $87,23 \%$ atau sudah masuk pada persentase baik.

Hasil pengelolaan data secara keseluruhan, dari sepuluh orang siswa ditemukan tujuh orang siswa masuk dalam kategori rendah dan tiga orang masuk kategori tinggi setelah diberikan layanan bimbingan kelompok. Hal tersebut menunjukkan ada tiga siswa mengalami peningkatan yang signifikan pada etika pergaulan yaitu RS, HSI dan SA. Dari lima indikator, RS menunjukkan peningkatan secara signifikan pada indikator kelima yaitu tidak mengejek dan indikator ketiga yaitu memberi salam dan menjawab salam atau keterampilan berkomunikasi dengan persentase awal $41,91 \%$ menjadi $80,14 \%$ sehingga siswa tersebut mengalami peningkatan sebesar $38,23 \%$. Sementara itu HSI menununjukkan peningkatan pada indikator kedua yaitu menghormati perasaan orang lain dengan persentase awal $44,11 \%$ menjadi $81,25 \%$ sehingga siswa tersebut mengalami peningkatan sebesar $37,14 \%$. Sedangkan SA menunjukkan peningkatan pada indikator keempat yaitu jangan mencari kesalahan orang lain dengan persentase awal $45,95 \%$ menjadi $77,20 \%$ sehingga mengalami peningkatan sebesar $31,25 \%$.

Siswa yang memiliki etika pergaulan yang rendah akan berdampak pada diri siswa seperti misalnya siswa selalu bertengkar dengan temannya, siswa tidak menghargai pendapat siswa lain, siswa tidak sopan dalam berbicara dengan siswa lain bahkan terhadap gurunya, oleh karena itu siswa tersebut selalu diberikan hukum oleh guru-guru yang ada di sekolah tersebut bahkan selalu dipanggil di ruang guru untuk mendapatkan hukuman dan mendapatkan surat panggilan untuk orang tuannya. Hal ini sesuai dengan pernyataan dari HSI saat proses pemberian layanan bimbingan kelompok HSI menyatakan bahwa ia pernah di hukum oleh guru karena tidak sopan dalam berbicara dengan teman. Oleh karena itu, bimbingan kelompok bertujuan untuk mendorong perasaan, pikiran, persepsi, wawasan dan sikap yang menunjang perwujudan tingkah laku yang lebih efektif baik kemampuan berkomunikasi verbal maupun non verbal.

Strike dan soltis (dalam Aggriani dkk, 2016: 69) mengemukakan etika pergaulan adalah suatu hubungan tingkah laku individu yang di dalamnya terdapat suatu norma dan nilai-nilai yang digunakan dalam kehidupan sehari-hari, serta merupakan tolak ukur tingkah laku individu yang digunakan 
masyarakat untuk menentukan baik buruknya suatu tindakan manusia dalam kehidupan sehari-hari.

Kemudian pernyataan RS saat proses pemberian layanan bimbingan kelompok RS menyatakan bahwa ia pernah bertengkar dengan temannya yang disebabkan saling mengejek dengan bahasa yang tidak sopan sehingga. Ungkapan RS menunjukkan bahwa dalam berkomunikasi dengan orang lain harus menggunakan bahasa yang sopan sehingga tidak terjadi kesalahpahaman antar sesama siswa kemudian dalam bermain tidak boleh mengejek satu sama lain sehingga tidak terjadi pertengkaran

\section{Kesimpulan dan Saran \\ Kesimpulan}

Berdasarkan hasil analisis data dan pembahasan, dapat diperoleh ditarik kesimpulan bahwa etika pergaulan siswa SMP Negeri 07 Kendari sebelum dan sesudah diberikan perlakuan/ treatment mengalami perubahan. Di ketahui bahwa sebelum diberikan perlakuan/ pre test tingkat etika pergaulan siswa masuk dalam kategori rendah dengan rata-rata $58.23 \%$, sedangkan setelah diberikan perlakuan/ post test tingkat etika pergaulan siswa berada pada kategori tinggi dengan rata-rata $81,47 \%$. Berdasarkn hasil uji wilcoxon signed rank test pada taraf signifikan $\alpha=0,05$. Kemudian dari hasil uji wilcoxon diperoleh $P_{\text {value }}=$ $0,005 . \mathrm{P}_{\text {value }}$ lebih kecil dari $\alpha(0,005<0,05)$ dengan demikian $\mathrm{H}_{\mathrm{a}}$ diterima. Maka dapat disimpulkan bahwa layanan bimbingan kelompok dapat berpengaruh secara signifikan terhadap etika pergaulan siswa di SMP Negeri 07 Kendari.

\section{Saran}

1. Bagi Kepala Sekolah, diharapkan ikut serta dalam mengontrol perkembangan siswa, serta menambah jumlah personel guru bimbingan dan konseling agar dalam pemberian layanan bisa lebih efektif serta menyediakan fasilitas penunjang kegiatan layanan bimbingan konseling

2. Bagi subjek, aplikasikan apa yang telah diperoleh melalui bimbingan kelompok dan berusaha mengembangkan kemampuan dan memiliki etika yang baik dalam bergaul agar dapat mengatasi hambatan yang muncul.

3. Bagi penelitian selanjutnya, hendaknya dapat mengembangkan dengan menggunakan metode yang lain untuk mengukur tingkat etika pergaulan siswa. Karena peneliti hanya menggunakan angket jadi diharapkan kepada peneliti selanjutnya dapat menggunakan metode yang lain agar bisa mengukur lebih baik etika pergaulan siswa.

\section{Daftar Pustaka}

Abdullah, Yatimin. M, (2006). Pengatar Studi Etika, Jakarta: PT Rajagrafindo Persada.

Abidin, Zaenal dan Alief Budiyono. (2010). Dasar-dasar Bimbingan dan Konseling. Yogyakarta: Grafindo Litera Media.

Bertens, K. (2013). Etika (edisi revisi). Yagyakarta: PT Kanisius.

Folastri, Sisca \& Itsar Bolo Rangka. (2016). Prosedur Layanan Bimbingan dan Konseling Kelompok. Bandung: Mujahid Press.

Hartinah, Sitti. (2009). Konsep Dasar Bimbingan Kelompok. Bandung: PT. Refika Aditam.

Kartilah. (2017). Upaya Meningkatkan Pemahaman Pergaulan Sehat Remaja Dalam Layanan Informasi Melalui Game Showball Thorowing Pada Siswa Kelas X MIPA 3 SMA Negeri 1 Ambarawa, Kabupaten Semarang Tahun Ajaran 2015/1016. Volume 4 nomor 2.

Latipun. (2002). Psikologi Eksperimen. Malang UMM Press.

Muhayati, Sri. (2013). Meningkatkan Keterampilan Etika Pergaulan Melalui Layanan Bimbingan Kelompok Pada Siswa Kelas VII F SMP Negeri 3 Demak tahun ajaran 2011/2012. Skripsi. Universitas Negeri Semarang.

Prayitno dan Erman Amti. (2013). Dasar-dasar Bimbingan dan Konseling: Jakarta: PT Rineka Cipta.

Rifai, Muh. Husyain, dkk. (2012). Etika Pergaulan Mahasiswa FKIP Universitas Veteran Bangun Nusantara Sukarno Tahun 2012. Jurnal Pendidikan. Volume 22 Nomor 3, November 2013.

Ruslan, Rosbandy. (2001). Etika Kehumasan Konsepsi dan Aplikasi. Jakarta: PT RajaGrafindo Perseda. 